\title{
Potential of Barriers to Proceedings in Court Using Internet
}

\author{
Yasser S. Wahab*, Ahmadi Miru**, Musakkir***, and Mustafa Bola**** \\ * PhD Students at Postgraduate Programme, Faculty of Law, Hasanuddin University \\ ** Professor on Legal Science, Faculty of Law, Hasanuddin University \\ *** Professor on Legal Science, Faculty of Law, Hasanuddin University \\ **** Associate Professor on Legal Science, Faculty of Law, Hasanuddin University \\ Corresponding Email: obe buyung@yahoo.com
}

\begin{abstract}
Article 2 paragraph (4) the Law Number 48 of 2009 concerning Judicial Power provides that judicial proceedings are conducted in a simple, quick, and low-cost manner. The entire scope of the court proceedings in Indonesia is basically divided into three parts, namely: the answering process of the parties, the process of evidence, and the decision making process. The use of internet media facilities is applied in the process of answering to each procedural law of all courts in Indonesia. It is necessary to have technical instructions regarding the mechanism contained in the Supreme Court Regulations and the Republic of Indonesia's Constitutional Court Regulations as guidelines for court administering courts.

Keywords: Obstacle to Court Proceeding, Internet.

DOI: $10.7176 / \mathrm{JLPG} / 89-06$

Publication date:September $30^{\text {th }} 2019$

\section{Introduction}

Based on Article 2 paragraph (4) the Law Number 48 of 2009 concerning Judicial Power, it provides that judicial proceedings are conducted in a simple, quick, and low-cost manner. The principle of simple, quick, and low cost (contante justitie) is the most fundamental judicial principle of the implementation and administration of judicial services that leads to the principles of effective and efficient. ${ }^{1}$
\end{abstract}

Simple is the examination and settlement of cases carried out in an efficient and effective manner. ${ }^{2}$ It can also be interpreted as a process that is not complicated, clear, straightforward, non-interpretable, easy to understand, easy to do, easy to implement, systematic, concrete both in the perspective of justice seekers and in the perspective of law enforcers who have the diversity level of qualification either in the field of educational potential possessed, socio-economic conditions, culture, or others. ${ }^{3}$ However, in practice, the simple principle is only limited to administrative problems without understanding that the simple principle must be the soul and motivated spirit of law enforcers that is carried out comprehensively at all levels and institutions.

Quick must be interpreted as a strategic effort to make the justice system as an institution that can guarantee the realization / achievement of justice in law enforcement quickly by justice seekers. ${ }^{4}$ In this context, the case is not only resolved quickly, but also the case shall consider juridical aspects, thoroughness, accuracy, and sociological considerations in order to guarantee a sense of community justice. This principle covers quick in term of processes, results, and evaluation the performance and productivity levels of the judiciary.

Low costs mean that case costs can be reached by the community. ${ }^{5}$ The low cost also means that seeking justice through a judicial institution is not just a person who has hope for justice in it but there must be guaranteed that justice is not expensive, not be materialized, independent justice, and free from other values that damage the value of justice itself. ${ }^{6}$ The principle of simple, quick, and low cost in examining and completing cases in court does not rule out accuracy and thoroughness in seeking truth and justice. ${ }^{7}$

In addition, there is also a principle of audi et alteram partem law in law enforcement in court. In terms of creating a trial to run in a balanced manner, both parties must be heard and given equal opportunities for justice. Judges may not accept information from only one party, without first hearing and giving the other party an opportunity to submit their opinions. ${ }^{8}$ Therefore, all procedural law in Indonesian courts requires an opportunity for balanced answers between the parties. The need to provide a balanced opportunity for both parties to the case certainly affects the application of the principle of contante justitie. It is because on the one hand the court must be held simple, quick, and low-cost, while on the other hand it must also provide sufficient and balanced opportunities for each party which would certainly take up time and money.

\footnotetext{
${ }^{1}$ Sunaryo et.al. 2005. Water Management Resources. Universitas Udayana, Denpasar. p. 46.

${ }^{2}$ See Explainatory of Article 2 paragraph 4 of the Law Number 48 of 2009.

${ }^{3}$ Sudarsono 1991. An Introduction of Indonesian Law. Rineka Cipta. Jakarta. p 58.

${ }^{4}$ Ibid. p.47.

${ }^{5}$ See Explainatory of Article 2 paragraph 4 of the Law Number 48 of 2009.

${ }^{6}$ Sudarsono, op.cit.p. 48.

${ }^{7}$ See Explainatory of Article 2 paragraph 4 of the Law Number 48 of 2009.

${ }^{8}$ Miftakhul Huda. 2009. Audi et Alteram Partem, Constitution Magazine Edition No.32 bulan September 2009, the Constitution Court, Jakarta, pp. 52-53.
} 
Almost all courts in Indonesia still apply rigid and traditional procedural law. This rigidity also includes keeping the stages of the proceedings process which is more time and costly than the benefits and objectives of the event itself. The proceedings process takes place both in civil court (general and special) and administrative court. Those courts are still known as the process of answering arguments / excuses that takes no less than 4 (four) weeks. In criminal courts (general and special) also known as the submission process exceptions and responses that take 3 (three) weeks, even the election dispute resolution in the Constitutional Court of the Republic of Indonesia which is well known as the speedy trial apparently still requires 2 (two) trials for the answer and answer process. Even though the submission for the improvement of the lawsuit and the conclusion is already using internet media.

In the context of the essence of the formal legal process of the answer's process as mentioned above, it is only to obtain confirmation of what matters are demanded by one party and how the response of the other party, which is only subjective, one-way and only constitutes formal information for the judge, which is not yet time to be debated, interrupted or not yet to be cross-examined by other parties. So the process that takes weeks. Basically, it is actually just a process of delivering, distributing and receiving letters, which should only take no more than 10 minutes. However, due to it must be done in front of the trial, the 10-minute process becomes swollen and can become a full day trial. It is because the parties should queue of the trial schedule on the same day and will be repeat for several weeks.

The process of answering is not only a waste of time for all parties, but it also takes a lot of money. For those who litigate in the court where they live, of course they still need transportation and lunch costs when attending the "10 minute" trial. Especially for parties residing in other cities of the court who tried the case, the costs also include long-distance transportation costs, lodging and consumption costs that are not insignificant each time attending the "letter handover" trial. The phenomenon of the proceedings above shows that the existing law is less able to support the development and change of life that occurs in society. ${ }^{1}$

Along with the times, the internet media is known. The development of internet media is apparently effective and efficient in accelerating the process of correspondence from one party to another. In the traditional correspondence system, it takes at least 1 (one) day to send / deliver until the letter reaches the intended party. Meanwhile, if you use e-mail, then the time can be shortened to a matter of seconds, and the cost required is also relatively very small compared to if the letter must be sent / delivered traditionally. However, the importance of effectiveness and efficiency in court proceedings certainly cannot simply be done by ignoring the substance of a fair and impartial examination. The Supreme Court of the Republic of Indonesia has issued the Republic of Indonesia Supreme Court Regulation No. 3 of 2018 concerning Guidelines for Case Administration in the Electronic Court, which was then followed by issuing the Republic of Indonesia Supreme Court Regulation No. 1 of 2019 concerning Administration of Cases and Trials in Electronic Courts. The focus of this article is to analyse how "digitalization" of the proceedings carried out, and what could be a potential obstacle in the implementation of the proceedings using Internet.

\section{Court Proceedings Using Internet}

The entire scope of the court proceedings in Indonesia, it is basically divided into three parts, namely: the answering process of the parties, the process of evidence, and the decision making process. The answering process, furthermore, takes place at least three times in the Indonesian Constitutional Court and at least five times in other trials. The distance between one trial and the next trial is usually between a delay of one week, except for the pre-trial and the hearing at the Constitutional Court of the Republic of Indonesia that is usually between with a delay of just one day.

This has become inefficient because the activities require months and a large amount of money to come to the place of trial and submit or receive documents. At the time of the answering process of trial, it is no cross-examination of the files submitted. In practice, it is only the submission and receipt of the answering process files from the party who in turn submitted.

In order to speed up the process and overcome the accumulation of cases in the courts, the Supreme Court has launched a court application electronically (e-court) based online, which is stipulated in the Supreme Court No. 3 of 2018 on Guidelines for Administrative Cases in Courts. Electronically, e-court regulates starting from users of case administration services, registration of case administration, summons of parties, issuance of copy of decisions, and administrative governance, payment of court fees which are all done electronically / online when submitting a petition / lawsuit, civil, religious, administrative state businesses that apply in each court environment. This e-court is expected to expedite the administration process and justice services for justice seekers, as well as to realize the principle of fast and low cost (contante justitie). This system is also expected to be able to summarize the mechanism of payment of court fees and minimize illegal fees. It is because the payment of court fees is connected to the e-payment system directly addressed to court accounts through electronic payment channels available at government banks namely Bank BTN, Bank BRI, BNI 46 Bank, BNI Syariah Bank, Mandiri Bank, and Mandiri Syariah Bank.

After the case registration is verified, furthermore, the applicant or claimant can immediately find out the case registration number online enough without the need to come to court. In addition, the system e-court is provided a mechanism

${ }^{1}$ Yasser S. Wahab. 1996. The Role of Economic Law in Indonesia to Welcome the 2020 Free Trade Area. Faculty of Law. Hasanuddin University, Ujung Pandang, p 5. 
for calling the electronic (e-summons) that are very quick and cost-saving to zero rupiah. This is because the summoning system for litigants can be carried out directly to the address of an electronic domicile, including eliminating the need for procedures for delegating summons through other courts. In the case of parties reside in different areas. However, this $e$ summon procedure can only be taken if the parties agree to make an electronic call.

E-court is the court of registration services, payment and dialling online in the courts under the Supreme Court (general courts, administrative courts, religious courts, and military courts). There are at least three applications carried by the Supreme Court in the e-court system, namely the registration of the case (e-filing), the payment of the down payment of the case money (e-payment) and the delivery of notifications and summons of electronic trials (e-summons). Through the case registration application (e-filing), for example, lawyers or the general public who are already registered. They can register lawsuits / requests electronically without having to come to court, elect an authorized court, register a special power of attorney, pay PNBP power of attorney, input the parties, uploading claim / application documents can be done electronically. Even to save time, response letters, replicas, duplicates and / or conclusions can be sent electronically without the need for a trial, provided the parties agree to use this application. If the calculations are counted, the parties only need to hear 4-6 times, that is, at the time of mediation, reading the lawsuit, examining witnesses, evidence, and reading the verdict.

For case payments, it can also be made by application (e-payment), where the plaintiff / applicant will later receive an estimated case fee down payment (e-SKUM) accompanied by a virtual electronic payment channel account code, then make a payment, and after receiving confirmation it will get case number after being registered in the case tracking information system (SIPP). The summons is no longer necessary by post or bailiff, the plaintiff will be summoned electronically (via e-mail), for the defendant / respondent to be called manually first, then for the next trial process can be done electronically as long as the second is approved parties. This application is also used to notify decisions electronically. Among the people who benefit the most from the application are lawyers. It is because of facilitating case registration, the trial schedule has been cut by almost half, so that advocates are more focused on research handling cases that are being handled.

The presence of the Supreme Court Regulation is also an answer for the people seeking justice (justitiabellen) who have been constrained by time, distance and cost. Not to mention the roads that are still in contoured land, plus for example there is an error in the format and substance of the lawsuit, it will take days to just take care of the case registration. This of course is a waste of time. Regarding this system, the down payment of court proceedings is even cheaper because electronic court summons are not paid or zero. It can be compared with the cost of a manual call using the radius system, for example the farthest call in the Sanggau Religious Court, the cost of a call for the furthest radius is around Rp. 500,000750,000 for the District of Belitung Hulu for one call. This fee is certainly very burdensome for justice seekers who are economically weak.

The Supreme Court then issued the Supreme Court Regulation No. 1 of 2019 concerning Case Administration and Trials in the Electronic Court. It is also referred to as e-court. This regulation still limits the use of this provision only in the scope of civil justice, religious civil law, military administration and state administration. The process can be carried out electronically including since the registration process, the process of answering, the process of verifying letters, the process of pronouncing decisions, appeals and cassation. The use of e-court is carried out in the form of an application, where the user must first have an account and be registered by default in the Supreme Court. The process for obtaining an account is regulated in Articles 5, 6 and 7 of this Regulation, and subsequently will be regulated technically by a Decree of the Chairperson Supreme Court. For the first time, the implementation of this regulation is tested in 6 District Courts, 4 Religious Courts, and 3 State Administrative Courts in Indonesia. The issuance of the Supreme Court Regulation No. 1 of 2019 has shown the anticipation of the Supreme Court on the development of electronic proceedings. The process can be carried out electronically since the registration process, the process of answering, the process of proving letters, the process of pronouncing decisions, appeals and cassation.

\section{Potential obstacles to using internet media in lawyers in Indonesia}

Regarding the existence of the Supreme Court Regulation No. 3 of 2018 and the Supreme Court Regulation No.1 2019 , it must still be harmonized to obtain effective and efficient results. Therefore, there are still various obstacles to the implementation of digitizing the proceedings using internet media, including:

$>$ This regulation is still contained in the form of a Supreme Court Regulation of the Republic of Indonesia, so that its scope is still limited and its strength does not originate from the legal sources referred to in the hierarchical laws. With the limitations of the scope and strength of the law, it allows the emergence of juridical constraints when dealing with different conditions but is still in line with the law. So this regulation should also be regulated in amendments / adjustments to the Judicial Power Act.

$>$ There are bureaucratic and inflexible provisions, such as the necessity of a standard user account and a permanent office address for the user, which will certainly slow down or limit access to the widespread use of this rule.

$>$ It still requires the approval of the parties, before agreeing to the trial through electronic media.

$>$ On the other hand, this regulation actually limits someone's right to be intervenient, where if someone requests to be intervenient. He is obliged to approve the electronic trial which is in progress. If they do not approve, then the application must be rejected by the judge to be intervenient.

$>$ The electronic trial stage also includes the witness verification process, while there are a number of things that are unfair when a witness is examined electronically, for example, when a spontaneous cross examination is not 
achieved, the witness's behaviour and way of answering are not so visible or heard, it does not guarantee that a witness is truly really free from the influence of others or did not hear the testimony of witnesses before, and so on.

$>$ Media is managed using an application system that is less flexible than regular e-mail.

$>$ Limit interventions that are illiterate or unable to convene electronically.

The challenge of use of total e-court in the "digitalization" in court proceedings must be able to overcome potential obstacles in the electronic media, namely:

First, the reality of internet network access that has not been evenly distributed in Indonesia, where based on data from the National Development Agency that there are still around 25,000 villages in Indonesia that have not enjoyed internet networks, mostly in Kalimantan, Sulawesi, Nusa Tenggara, and Papua where most of the regions are lagging behind, front, and outermost. So the government must be able to build an internet network that reaches to these areas before the digitalization of the proceedings can be carried out thoroughly.

Second, the threat of attacks from hackers. The hacker can attack any institution that they consider important, even in the year 2013 hackers have even attacked the court institutions, such as the District Court Unaaha, Southeast Sulawesi and the State District Court, Bali. The hackers at that time do damage to the internet network for months, among others by distributing photos that smelled of racial intolerance and pornography. It can be imagined if this is not anticipated in the use of e-court, then it could be for example hackers manipulating summons and trial schedules, which appear to be summoned via e-mail even though the court never made the summons.

Third, it is possible to implement e-court applications well if judges and court employees are still " technologically illiterate "? The Supreme Court must be able to answer this challenge by recruiting prospective judges who are no longer " technologically illiterate". The fact is the majority of employees and judges are still many who are still "technology illiterate", especially those aged 50 years and over.

\section{Conclusion}

There is a need to change the procedural law provisions that apply to the courts of first instance under the Supreme Court of the Republic of Indonesia and to the Constitutional Court. It is to accommodate the possibility of using the internet media in the process of answering answers in case trials. As the highest legal umbrella in the implementation of the judicial system throughout Indonesia, of course the amendment is very necessary in the provisions of the Law Number 48 of 2009 concerning Judicial Power.

The use of internet media facilities in the process of answering can be applied to each procedural law of all courts in Indonesia. It is necessary to have technical instructions regarding the mechanism contained in the Supreme Court Regulations and the Republic of Indonesia's Constitutional Court Regulations as guidelines for court administering courts. Technical regulation must be more effective and efficient than the existing the Supreme Court Regulation No. 1 of 2019.

\section{Bibliography}

Miftakhul Huda. 2009. Audi et Alteram Partem, Constitution Magazine Edition No.32 bulan September 2009, the Constitution Court, Jakarta.

Sunaryo et.al. 2005. Water Management Resources. Universitas Udayana, Denpasar.

Sudarsono 1991. An Introduction of Indonesian Law. Rineka Cipta. Jakarta.

Yasser S. Wahab. 1996. The Role of Economic Law in Indonesia to Welcome the 2020 Free Trade Area. Faculty of Law. Hasanuddin University, Ujung Pandang. 